\title{
SOCIAL EDUCATION OF EARLY MARRIAGE (PRE-MARRIAGE PREGNANCY IN GOWA DISTRICT, SOUTH SULAWESI)
}

\author{
Sam'un Mukramin, Halawatiah \\ Department of Sociology Education, \\ University of Muhammadiyah, Makassar \\ sam'un.mukramin@unismuh.ac.id
}

\begin{abstract}
Early marriage was underage marriage, one of the reasons for the occurrence of pre-marriage pregnancy in Indonesia. This research used descriptive qualitative method, with informants of early marriage, family of perpetrators, public figure and government agencies. Data collecting were using observation, interviews and documentation. The results of this study indicate that the factors causing the occurrence of early marriage due to: (i) the influence of promiscuity (dating); (ii). the influence of the development of information technology (internet and mass media); (iii). poor parental and community supervision; (iv). the availability of the affordable lodging facilities; (v) lack of adolescent religious understanding. Pre-marriage pregnancy is done through: (i). official marriage; (ii). the unacknowledged marriage of law or siri'; (iii). the process of eloping; and (iv). the contractual agreement between the parents.
\end{abstract}

Keywords: marriage, early, pregnancy, deviation

\section{INTRODUCTION}

According to the Law No. 1 of 1974 on Marriage, the meaning of marriage is: "The inner birth bond between a man and a woman as husband and wife in order to form a happy and eternal family (household) based on Belief on God". (Marriage Law, No. 1/1974). In the language review, marriage is defined as marriage. But in some areas it is often distinguished between marriage and wedding. Wedding has a narrower meaning because it is identical with physical relations alone. According to the Indonesian General Dictionary (Poerwa Darminta, 2002), marriage is the same as wedding, the word marriage is wedding of men and women to husband and wife.

One of the deviations that teens are related to the promiscuity that causes the occurrence of pre-marriage pregnancy is a social reality in people's lives. According 
to sociological reviews this case can be classified in a social fact paradigm because it involves the social values and norms that exist in Durkheim society (Ritzer, 2010: 14). In the perspective of the social fact paradigm, getting pregnancypremarriage is a form of violation of values and cultural norms of society. Value means the quality of the social system of society, while the norm is the order or the rules that become the handle in behaving in order to realize social order.

Pregnancy is as a form of deviation behavior of adult can also be viewed from the paradigm of social behavior, because in its development has a reciprocal relationship and influence each other on the existing social environment. Social structure, in this case family, government and society that do not function maximally as social control, causing adolescent feel free to do whatever they liked with the assumption as long as not harm others.

According to Phelp (Syani, 2007: 183) causes of social problems, among others due to economic factors, biological, psychological and cultural factors. Therefore, the authors assume that premarriage pregnancy is basically a social problem with reasons such as: (1) Premarriage pregnancy is a deviation of normative behavior, because of the social sanction that the family will feel an uncomfortable life, because concerning self-esteem (2) pre-marriage pregnancy is a phenomenon that requires attention, seriousness, awareness and cooperation from various parties (family, government and society), (3) need to concern society about pregnancy case pre-marriage happened on adult, so that there is need of effort and concrete act in handling it.
Pregnancy cases in Kecamatan Tinggimoncong Gowa district that tend to happen is a courting couple. They consider that "dating" is a common thing and if you do not have a girlfriend is considered as out of date. In addition, many factors that encourage children to date, such as lifestyle that is influenced by outside culture, lack of knowledge about sex, lack of attention to religion, free relationship is the influence of peers or the environment, parents who give freedom to children to associate with the opposite sex without strict supervision of them because of busyness and several factors such as economic factors, education or parenting, mass media and the influence of globalization.

In fact, it is not just an inn that is used as a place to commit immoral acts of teenagers, a predominantly pine-forest district of Tinggimoncong and gardens covered with tall trees and a quiet atmosphere into a place that teenagers use to date and even have sex.

Pregnancy marriage cases ultimately impact on early marriage to be done by adult, as both are married in a forced way to reduce and mask the shame that the family endures and the protection of women who become pregnancy victims pre-marriage and the victims of derision from the surrounding community.

The Child Protection Act provides that parents are responsible and responsible for preventing marriage by the age of the children. Principles adhered to in the Marriage Law as well as the Child Protection Act, although both laws specify different ages in the determination of maturity, but do not desire the occurrence of underage marriages. Only the law does not include strict sanctions in case 
of marriage violation is a civil matter so that if a marriage underage occurs then the marriage is declared ineligible and can be canceled.

Early marriage especially in Kecamatan Tinggimoncong gives various effects and various problems that arise in the life of the household due to unpreparedness mentally and materially in building a household such as economic problems because men as breadwinner has no permanent job, violence in households because of the emotional age of those who are still unstable, even the occurrence of divorce due to inability to overcome the existing household problems.

According to Diane E. Papalia and Wendkos (1995), suggests that the best age for marriage for women is 19 to 25 years, while for males aged 25 to 28 are expected to be married, as this is the best age to marry either for start a home life or to take care of the first child. According to Sarwono (2002) in the age of less than 21 years old a child, if they want to marry must have the permission of parents, and the Office of Religious Affairs (KUA) will not marry them before the permission of parents.

\section{RESEARCH METHOD}

This research is a qualitative descriptive that describes in detail about the symptoms in a group in this case is marriage at earlier age or youth with base of research used is case study. The target of the research is in Tinggimoncong District of Gowa Regency. The selection of informants in this study was determined purposively (summed purposive) in accordance with the criteria and objectives and the selection of informants by using the snowball sampling (snowball) that is the selection of informants that may be obtained from previous informants or from public information.

Observation, interviews and documentation are data collection techniques by directly observing the subjects (research subjects) and recording events and behaviors in a reasonable and detailed way. The data obtained from the research is analyzed descriptive qualitatively by giving the description of the informant clearly and deeply as the use of case study research method.

\section{RESULTS AND DISCUSSIONS}

\section{Factors Causing Early Marriage and Pre-Marriage Pregnancy}

\section{The Influence of Intercourse (Dating)}

The freedom of making friends at school age teens have an impact on free sex behavior in adult which is a form of deviation of values and norms in the cultural order of society. This means free sex is closely related to the morality of adult in their daily life.

Teenagers might be defined as a time to develop the behavior of individual teens. For that, a sociological approach to adolescent development is needed to obtain objective data against it. The sociological approach is intended to understand the social life of adult. This means how to understand the world of adult, because adult is a period of forming and developing personality. So, the teenager socialize, that is live in the society, able to adjust to the rules, culture, values that exist, especially religion, so as to reach the level of perfect maturity. 
Teenage free sex that leads to free sex is essentially one of the effects of the imperfect socialization they do because they are affected by the increasingly unlimited free sex, they imitate something distorted, like free sex that causes the occurrence of early marriage in the case pre-marriage pregnancy. Free interaction has an impact on social change, especially changes concerning the system of values and norms of society (pranata). The values and norms of local culture that should be the guidance of life are ruled out by teenagers. Pregnancy outside the legitimate marriage bond is a logical consequence that adult should receive due to lack of education and knowledge of sex. It also causes the mental unpreparedness of adult to become parents for their children is very lacking, so greatly affect the lives of his family, especially the growth of his kid.

\section{The Influence of Information Technology Development}

Mukramin and Suardi (2017), stated as it is known that, the influence of the current modernization and globalization that has penetrated into all aspects of social life of society, making people experience significant changes that affect the individual personality. The influence of the development of information technology, especially internet or other mass media functionally serves to convey information to the public. Various information can be accessed by mass media (internet, newspaper, television and others), including information about sexual problems, teenagers easily accessing pornographic videos or pornographic images through mass media.
Anything that teenagers get through the media will in some way influence the lives of those who are still unstable and a high curiosity towards what they see will again affect the sexual behavior patterns of teenagers whose personality is still in the formation period. Mass media assessed to give a big share in the occurrence of promiscuity among adult that ultimately lead to premarriage pregnancy. The development of communications technology, especially mobile communication media or smart phone also contributed greatly in the world of adult, as well as information technology (mass media), smart phone became a means of communication for teenagers in this case between men and women via SMS facilities, MMS or phone directly.

In addition, smart phone everyday facilities are undergoing developments in the development of technology and information, smart phone manufacturers and providers provide the facility with features that make it easier for its users to communicate, information via smart phone, internet facilities and many other features. Even some cases found in this study that smart phone is one of the triggers of early marriage because of premarriage pregnancy.

Parents sometimes follow the wishes of their children by providing smart phone facilities in the hope of facilitating communication due to the distance between home and school are far enough with a field or road conditions are quite vulnerable because it is a highland or mountainous areas. But the facilities provided are detached from parental controls, because sometimes people do not know the facilities available on smart phone, they also do not control 
what features their children use on smart phone. This is what sometimes makes children free because their parents do not control the means of communication provided by their parents.

Based on the data that researchers obtain in relation to deviant behavior, the control theory in deviant behavior in this case the control of parents, family and community in the use of communication tools that are less to the child will result in the occurrence of uncontrolled associations on teenager whose soul is still very unstable.

\section{Poor of Monitoring from Parents and Community}

Lack of control results in the occurrence of pre-marriage pregnancy in school-aged children in Hirachi's behavioral theory (Narwoko, et al, 2007: 116) states that there are at least 4 major elements of social control that can be done by people parents, educational institutions and the community are: affection (attachment), responsibility (commitment), involvement or participation (involvement), trust or belief (believe). The fourth thing is considered able to be used as a social control in society to control the behavior of individuals in society so as not to deviate.

Likewise, the less parent's responsibility to the child will make the child not have internalization of values and strong norms in him or her because it will be so easily affected by the negative things in their life because they are not able to control themselves, they will not be able to filter the influence of modernization and globalization one of which is promiscuity.

\section{The Availability of Affordable Accommodation Facilities}

Problems arising from innumerable lodgings such as villas, hotels, guesthouses, and community homes where lodging is available without the control of both the government and the public will have an effect on others. The number of couples who visit then rent a room with no prior examination whether they are husband or wife or not, the price is very affordable lodging provides an example for our teens to access the place.

\section{Lack of Understanding of Religion}

The cultivation of religious values from an early age in the modernization and globalization era is indeed very important, because modernization and globalization in culture are for example a social process that sociologically will bring about a changing effect for a culture. Social and cultural changes will have an impact on lifestyle changes and people's behavior. Pregnancy cases are issues that are part of the regulated values and norms in society. Modernization and globalization of culture will prove in the culture of society as a result of a shift in the sacred value of a woman's sacredness because of pre-marriage pregnancy.

The decline of values, social norms and religion in the life of society so that many cases that occur that violate the rules of social life, women no longer have shame (siri ') so that early age has lost sanctity and pregnancy not in marriage bonds. A shift in orientation where adult no longer maintain their sanctity and honor by taking actions or behaviors that deviate from the values and norms prevailing in society. 
One of the causes of the decline in the religious values of school-age youth today that researchers see in this Kecamatan Tinggimoncong region is the increasing number of tourist both foreign and domestic tourists are able to bring new forms of culture that are considered teenagers as a change and progress life so it is worth following. In such circumstances, the existence of local culture and the value of its wisdom is slowly ignored by the youth and is only a pride but not a reference to life and an antidote to the decline of religious values.

The main adolescent of women no longer considers that the sanctity of a woman is a pride for her and for her parents, so when a pregnancy before going to marriage will be a disgrace her and his family for not being able to keep his honor. They no longer pay attention to the values, social or religious norms that should be normative references in their association, thus engaging in premarital sex.

\section{Early Marriage and Pre-Marital Pregnancy Cases}

Early marriage processes that occur in the field in fact not in line with the rules or laws that apply, especially in cases of pre-marriage pregnancy, following some processes that are often done by the community, especially early marriage in the case of pre-marriage pregnancy. If, through formal marriage, the marriage process shall be in accordance with the requirements of the marriage law, that the procedure for marriage of a minor shall be to request dispensation from the court which shall grant permission to KUA and the register of marriage certificate to record and publish marriage book for married couples under that age.

The formal marriage process also some do but not through the handling of the dispensation to the court, but by changing the administration of residence that the parents increase the age of the child according to age limit to marry in related agencies can get permit through the village and then submitted to the KUA to appoint a priest or prince to marry the couple.

Under-hand marriage or siri' wedding is a marriage that is not disobeyed to the KUA. The marriage process conducted in the case of pre-marriage pregnancy in the community is through siri 'marriage or marriage under the hand, in this case not recorded in the KUA as the Official Marriage Registrar (VAT).

In some cases researchers have found parents who do not register their child's marriage, so they marry off their children without being reported to the parties due to several reasons:

\section{The process of elopement (silariang)}

Early marriage processes that occurred in the District of Tinggimoncong in general are not in accordance with the procedures governing the law. One of the marriage processes done by young couple is eloped (silariang). Silariang is meant to be a running mate in which the men and women agree beforehand to leave their homes and marry them elsewhere.

In Makassar society, known 3 forms of elopement that is: (1) Silariang (2) Nilariang (3) Nilari or erang kale. Nilariang means escaping where the woman is taken away without prior consent in this case the men forced the woman to be 
run to marry. Nilari or moan kale means a running mate, where the woman who comes to the house in the man or directly deals with the priest, asks to be married to the designated man on the grounds that the man has done something disgraceful or sexual abuse towards him. case Silariang namely the elopement that occurs because of the will together to ask for protection to the family who are far from where they both live to be wed through the imam. (1) They are afraid of pregnancy that occurred premarriage (2) The male party feels unable to meet the money that will be requested when married officially according to the prevailing customs. Although the process of elopement they do only a few months, because the parents are finally willing to accept them back or akbajik' and finally by both parents they married them officially.

\section{Through a contract marriage (agreement between both parents)}

The contract marriage in the research obtained is defined as a marriage that is performed only to cover up the embarrassment of the community's family to give the term a marriage Pattongko siri, paempo siri, or pa'dongko siri'. This marriage is still following the rules of Makassar customs that bring the shopping money or money as the request of the women when they are married by the Imam without being registered in the KUA, this marriage is followed by a promise that after the marriage is done then after that they divorce, so the male party may abandon the woman because such a contract or contract is accordingly born to be taken by the female family, in the case of the found child being born in status to be the child of the woman's parent.

\section{Impacts on the Actors and Families}

Shame or siri 'is associated with feelings of shame that must be borne by individual actors and for the family. Embarrassment is one of the views of values in cultural life and customs for the Bugis-Makassar, as well as the people of Kecamatan Tinggimoncong of Gowa Regency still uphold the siri culture.

According to Mattulada (1974: 49) that: Siri 'is related to the awareness of the value of dignity supported by each person in the tradition of Makassar society life. Siri is associated with a very sensitive collective consciousness, imposed upon each person in the tradition of the life of society in particular. The point is that siri 'is nothing but dignity and human dignity. Furthermore, according to Mahmud Tang (Bangka, 2010: 31) that a 'wrong' act is considered as an act of shame or appakasiri '(a violation of selfesteem) is deemed to be re-established or restored.

Therefore, for the people of Makassar, meaning that siri 'is part of his life. When life is without siri then the person is no more than animal life. Pregnancy cases in siri concepts 'is something very important in society because of the BugisMakassar culture that greatly upholds the philosophy of siri'. A girl who becomes pre-marriage pregnancy will give a shame and embarrassment to her and her extended family for having violated the customs, values and norms prevailing in society. A girl who is pre-marriage pregnancy will lose self-esteem (siri') for losing her sanctity when she has not been officially married according to the custom and the governing religion. The impacts of the perpetrators and their families are: 


\section{1) Feelings of Shame/Siri'}

The value of shame or siri' in the cultural value system of siri' contains a phrase based on feelings of shame for having committed a disgraceful act, violating the values and norms prevailing in society. The existence of shame in siri culture serves as an attempt to curb or be a controller for a person not to commit a disgraceful act and violate the values and norms of society.

Pre-marriage pregnancy cases that occur in adolescence is an act that violates the values and norms and rules of religion prevailing in society. A girl who gets premarriage pregnancy will have a huge psychological and sociological impact. This case shows that shyness or siri' no longer works for these adult to control themselves so as to commit acts that violate values and norms and provide shame for individuals and families.

A woman who is pre-marriage pregnancy is psychologically burdened with her pregnancy and sociologically becomes ridicule, gossip, and may even be ostracized in the life of the masses, since pre-marriage pregnancy is similar to a loss of self-esteem for a woman.

\section{2) Losing Self-Esteem as a Woman}

Self-esteem means honor or dignity. Self-esteem (Dignity) will be a control for a person not to commit a disgraceful act that violates the values and norms in society, because this self-esteem is related to the honorific value of himself as an individual (individual) and as a member of society. Pre-marriage pregnancy cases that often occur in Kecamatan Tinggimoncong for teenagers is a problem that is considered that teenage girls who become pre- marriage pregnancy are women who do not have dignity and are seen as people who lose the shame because a woman who lost sanctity pre-marriage regarded as a person who cannot keep his pride. The absence of shame in a person makes the individual concern as a person of no self-esteem.

Basically every human being is in need of self-esteem therefore everyone should have high self-esteem for human beings to be meaningful or valuable, especially for women will be an invaluable treasure if able to keep his pride as an honor for himself and his family.

\section{3) The Unwanted Child Labeled on the Born Child}

Pregnancy cases not only affect the perpetrators and parents but also the children who are born labeled as illegitimate children, even though both parents have been officially married. Early marriage in the case of pregnancy pre-marriage is part of the form of imperfect socialization in a family, it is very important we pay attention to strengthen the foundation of values and social norms in the family and in the life of the community. Strengthening the foundation of the family will provide family resilience and encourage strengthening in the community so that later on the children in interaction will be in accordance with the values and norms that apply.

The family as the main pillar with its binding functions is expected to be a social control for its members in order not to do deviant behavior. Pregnancy cases for school-aged youth cannot be separated from the inability of the role 
and function of family institutions to instill good values for their children.

Early marriage in the case of pregnancy pre-marriage is an act that deviates from the norms of marriage customs, religious norms of the subdistrict community Tinggimoncong, unfavorable and dishonest deeds and deprives the dignity and dignity of a woman, as well as for the family because the main family of both women will be regarded by the public not to guard, educate his daughter so as to do acts that remove her self-esteem as a woman.

Another impact caused by the occurrence of pregnancy pre-marriage for the families of both parties will give shame, because it will be the subject of conversation or gossip in both the immediate family and other communities. In addition, it will add a burden to the family because their children who are forced to marry because of the pregnancy is not ready mentally or materially to marry, then indirectly will be the responsibility of parents to bear the lives of their children.

Young marriage has an impact on the frequency of conflicts between family members between the child and the parents and between the daughtersin-law and in-laws. This is due to the unpreparedness of the couple to live in marriage, making it vulnerable to family disputes. In addition, economic problems become a problem that is quite vulnerable to the impact of marriage of the age that is still not mature in terms of physical and mental, psychological as well as the fulfillment of economic needs for husbands who do not have a job because they do not have the diploma, skills and ability to work.

\section{CONCLUSION}

Based on the disclosure of facts in the field obtained from various informants about early marriage case that happened in Kecamatan Moncongtinggi, Gowa Regency, hence researcher can draw conclusion as follows:

1. Factors that causing pre-marriage pregnancy is due to the influence of promiscuity, influence of technology and information development (internet), communication development, lack of supervision of parents and community, availability of affordable facilities, lack of understanding of religion for teens.

2. The rise of early marriage cases are through the process of formal marriage by way of age, through marriage brought by hand or siri, through the process of elopement, or through marriage of the contract of society termed as paempo siri', padongko siri', siri' atau patongko siri'.

The impacts that occur for the perpetrators of early marriage and family include: 1) feelings of shame or siri' for women who have lost their sanctity because pre-marriage pregnancy by violating the values and norms of religion and customs prevailing in society; 2) loss self-esteem for a woman because she is pregnant, her dignity as a woman has been lost because she feels guilty, fear will not be accepted by society, gossip or conversation from the community will have an impact on her psychology; 3) Label of unwanted child for child born after birth after both her parents were married. 


\section{BIBLIOGRAPHY}

Ahmad. 2009. Pernikahan Dini Masalah Kita Bersama. http://pa. bantul.net.id Diakses 29 Februari 2018.

Al-Husaini, Aiman. 2008. Tahun Pertama Pernikahan. Bandung: Universitas Pendidikan Bandung.

Al-Gifari. 2009. Hamil di Luar Nikah, Trend atau Aib. Bandung: Mujahid.

Aswar, Saifuddin. 1999. Metode Penelitian. Cetakan Kedua. Yogyakarta: Pustaka Pelajar.

Bangka, Herawaty. 2010. SILARIANG (Kasus Pada Beberapa Keluarga Di Kecamatan Batang, Kabupaten Jeneponto). Tesis. Makassar: Universitas Negeri Makassar

Bungin, Burhan. 2011. Penelitian Kualitatif Edisi Kedua. Jakarta: PT. Prenada Media Group.

Dianne E. Papalia, dan Wendkos, Sally. 1995. Human Development: Psikologi Perkembangan. Malang: Universitas Negeri Malang.

Hendi, Suhendi, dan Wahyu. R. 2001. Pengantar Studi Sosiologi Keluarga. Bandung: CV. Pustaka Setia.

Jalaluddin. 2007. Pergaulan Bebas. Jakarta: Al-Huda.

Marzuki, Laica. 1995. SIRI': Bagian Kesadaran Hukum Rakyat BugisMakassar. Makassar: Hasanuddin University Press.

Moleong, J. Lexy. 1991. Metode Penelitian Kualitatif. Cetakan Ketiga. Bandung: PT. Remaja Rosda Karya.

Mukramin, Sam'un dan Suardi. 2017. Interelasi Tradisi-Modernisasi pada Masyarakat Towuti. Kabupaten Luwu Timur. Jurnal Equilibrium Pendidikan Sosiologi Vol. V Mei No. 1 2017, 66-76.

Poerwadarminta. 2002. Kamus Umum
Bahasa Indonesia. Jakarta: Balai Pustaka.

Ra'ad, Kamil Mustadja, Al Hiyali. 2001. Membina Rumah Tangga Yang Harmonis. Jakarta: Pustaka Azzan. Jakarta.

Ritzer, George. 2010. Sosiologi: Ilmu Pengetahuan Berparadigma Ganda. Jakarta: PT. Raja Grafindo Persada.

Wirawan, Sarlito. 2002. Psikologi Remaja. Edisi Revisi. Jakarta: PT. Rajagrafindo Persada.

Shapiro. 2000. Mencegah Perkawinan yang Tidak Bahagia. Jakarta: Kanisius.

Syani, Abdul. 2007. Sosiologi, Sistematika, Teori dan Terapan. Jakarta: Bumi Aksara.

Soekanto, Soerjono. 2000. Pengantar Sosiologi. Jakarta: PT. Rajagrafindo Persada.

Sugiyono. 2011. Metode Penelitian Pendidikan: Pendekatan Kuantitatif, Kualitatif, dan RED. Bandung: Alfabeta.

Undang-Undang RI No. 1 Tahun 1974. Tentang Perkawinan dan Kompilasi Hukum Islam. Yogyakarta: Pustaka Yudistira.

Undang-Undang Perlindungan Anak $\mathcal{E}$ Undang-Undang RI No. 11 Tahun. 2012 Tentang Sistem Peradilan Pidana Anak. Jakarta: Permata Press. 